\title{
ANALISIS KEBIJAKAN ASASMEN NASIONAL PENGGANTI UJIAN NASIONAL DALAM EVALUASI AKHIR PENDIDIKAN
}

\author{
Silla ${ }^{\mathrm{i}}$, Melisa ${ }^{\mathrm{ii}}$, Rizky ${ }^{\mathrm{iii}}$ \\ 'Universitas Brawijaya, Falkutas Ilmu Administrasi, Prodi Administrasi Pendidikan \\ Nim : 195030901111017 \\ i" Universitas Brawijaya, Falkutas Ilmu Administrasi, Prodi Administrasi Pendidikan \\ Nim : 195030901111011 \\ iii Universitas Brawijaya, Falkutas Ilmu Administrasi, Prodi Administrasi Pendidikan
}

Nim : 195030907111015

\begin{abstract}
Abstrak
Munculnya Kebijakan Asasmen Nasional sebagai gantinya ujian nasional oleh Menteri Pendidikan Nadiem Makarim pada Tahun 2021, dimana nantinya ujian nasional bukan lagi hal yang menjadi tuntutan kelulusan peserta didik di kedepannya namun nantinya peserta didik diharapkan untuk menguasai Kebijakan system asasmen nasional dimana terdapat kemampuan bernalar dalam memahami suatu bacaan (literasi), kemampuan mengaplikasikan suatu metode hitung menghitung atau matematika (numerasi), dan survet karakter yaitu sebuah penilaian untuk peserta didik mengetahui keamanan, kerukunan, kondisi lingkungan rumah, kondisi lingkungan sekolah (terdapat bullying dsb), dan akhlak dari para peserta didik. Siswa dan siswi di sekolah akan ditanyai hal yang mudah seperti gotong royong, Bhineka Tunggal Ika, bukan ditanyai mengenai esensi dari asas Pancasila. Hal tersebut memberikan evaluasi bagi guru, wali murid, dan peserta didik, serta pendapat dari penghapusannya ujian nasional yang diganti menjadi asasmen nasional.
\end{abstract}

Kata Kunci : Evaluasi, Asasmen Nasional, dan Analisis

\begin{abstract}
The emergence of the National Assessment Policy instead of the national exam by the Minister of Education Nadiem Makarim in 2021, where later the national exam will no longer be a demand for student graduation in the future, but later students are expected to master the national assessment system policy where there is reasoning ability in understanding a reading (literacy), the ability to apply a method of counting or mathematics (numbering), and a character survey, which is an assessment for students to know security, harmony, home environmental conditions, school environmental conditions (there is bullying, etc.), and the morals of the students. learners. Students at school will be asked easy things such as mutual cooperation, Bhineka Tunggal Ika, not questions about the essence of the Pancasila principle. This provides evaluations for teachers, parents, and students, as well as opinions on the abolition of the national exam which has been replaced with a national assessment.
\end{abstract}

Keywords: Evaluation, National Assessment, and Analysis 


\section{PENDAHULUAN}

Ujian Nasional (UN) merupakan penilaian evaluasi standar pendidikan dasar dan menengah secara bersama di Indonesia untuk meningkatkan mutu pendidikan antar daerah yang dilakukan oleh pusat penilaian pendidikan Depdiknas di Indonesia dan mengacu pada Undang-Undang Republik Indonesia nomor 20 tahun 2003 pada pasal 57 (ayat 1) tentang evaluasi dilakukan dalam rangka pengendalian mutu pendidikan secara nasional sebagai bentuk akuntabilitas penyelenggara pendidikan kepada pihakpihak yang berkepentingan. Kebijakan pemerintah yang membuat Ujian Nasioal ini digunakan sebagai sarana untuk meningkatkan kualitas bangsa, denga Ujian Nasional sebagai patokan evaluasi akhir pendidikan ini dapat membantu membandingkan tingkat kualitas pendidikan bangsa saat ini dengan tahun sebelumnya. Awal mulanya diadakannya ujian nasional pada tahun 1965 dimana pada saat itu ujian tersebut dijadikan patokan kelulusan. Setelah itu pada tahun 1980 ujian nasional ini dikenal dengan nama EBTANAS (evaluasi Belajar Tahap Akhir Nasional), lalu pada tahun 2000 dikenal dengan UAN (Ujian Akhir Nasional), dan sampai tahun 2019 dikenal dengan nama UN (Ujian Nasional).
Tujuan pemerintah sendiri membuat Ujian Nasional yaitu untuk mengetahui standar penilaian yang bertarafi nasional di Indonesia dimana hal tersebut sangat penting dimata dunia. Namun, pada kenyataannya, ujian nasional penerapannya masih belum lancar dengan apa yang dituju oleh pemerintah. Pemerintah telah menjadikan kemampuan kognitif sebagai syarat pendidikan dimana potensi seorang siswa tidak hanya dilihat dari satu kemampuan saja melainkan masih ada kemampuan afektif dan psikomotorik.

Menurut Undang-Undang Nomor 20 Tahun 2003, tentang system Pendidikan Nasional, pasal 65 dan 66 yang membahas tentang penilaian dan menentukan kelulusan adalah pihak sekolah. Karena pihak skolah merupakan orang yang berinteraksi langsung terhadap muridnya dan mengetahui secara langsung kemampuan yang dimiliki siswa didiknya. Oleh karena itu dibuatnya ujian nasional untuk evaluasi akhir pendidikan sangat kurang efektif untuk realita di sekolah karena memberikan dampak negative pada muridnya, guru, orang tua, dan masyarakat. Bagi murid tersebut menyelenggarakan ujian nasionan memberikan beban psikologis siswa terganggu karena siswa terlalu dituntut menyelesaikan soal sehingga muncul persaingan antar siswa di sekolah. Untuk 
mencapai nilai yang bagus siswa harus merelakan waktu istirahatnya (bermain) yang mengakibatkan siswa akan jenuh. Dari sisi orang tua pun menuntut anaknya untuk lulus ujian nasional tanpa tahu apa yang dialami oleh anaknya. Bagi sekolah hanya untuk pencitraan yang baik, karenahasil lulusan akan mencerminkan sekolah yang baik di mata masyarakat setempat.

Maka dari itu evaluasi pendidikan adalah satu komponen yang penting dari perencanaan pendidikan. Namun tidak semua evaluasi dipakai untuk membandingkan/mengukur hasil pencapaian pendidikan yang telah ditujukan. Tingat keberhasilan pencapaian pendidikan dapat dilihat apabila jika alat evaluasi yang digunakan sesuai dan dapat diukur. Jika alat ukur tersebut tidak relevan maka hasilnya akan tidak tepat bahkan salah.

Akan tetapi, ujian nasional memiliki tujuan yang penting yaitu menjadikan tolak ukur pencapaian target pembelajaran yang datanya dapat digunakan oleh sekolah untuk memperbaiki model pembelajaran yang telah dilakukan selama ini. Pemerintah memakai hal tersebut untuk mendiagnosis ketingkatan kompetensi keguruan di Indonesia, namun tujuan pentingnya tidak terlaksana secara efektif. Terjadi kecurangan dari pihak percetakan, maupun orang yang menjual- belikan kunci jawaban. Kurang efektifnya penyelenggara ujian untuk evaluasi pendidikan akhir antara lain karena lemahnya koordinasi antara pemerintah daerah untuk mengoptimalkan pengawasan distribusi soal dari pusat sehingga sampai ketingkat daerah. Di infokan bahwa pada tahun ini (2021) akan dihapuskan ujian nasional dan diganti dengan system assessment nasional oleh menteri pendidikan Indonedia Nadiem Makarim.

Perubahan yang terjadi akan terdiri dati kemampuan bernalar dalam memahami suatu bacaan literasi), kemampuan mengaplikasikan suatu metode hitung menghitung atau matematika (numerasi), dan survet karakter yaitu sebuah penilaian untuk peserta didik mengetahui keamanan, kerukunan, kondisi lingkungan rumah, kondisi lingkungan sekolah (terdapat bullying dsb), dan akhlak dari para peserta didik. Dari dibuatnya assessment nasional ini membuat pro dan kontra dari berbagai pihan yang menjelaskan tentang sisi positif dan negative dari sebuah perubahan yang akan terjadi. Perubahan pelaksanaan ujian yang awalnya diakhir jenjang akan diadakan di pertengahan jenjang, hal ini menimbulkan banyak sekali pendapat tentang perubahan pelaksanaan ujian tersebut. Berdasarkan hal tersebut maka penulis mengangkat judul yaitu analisis Kebijakan asesmen nasional 
penganti ujian nasional sebagai pengganti evaluasi akhir pendidikan.

\section{METODE PENELITIAN}

Penelitian ini bersifat kualitatif. Menurut Bogdan dan Taylor terhadap penelitian ini yaitu "penelitian kualitatif merupakan suatu prosedur atau cara yang menghasilkan data deskriptif dalam bentuk ucapan maupun tulisan melalui sikap orangorang yang diamati”.

Menurut Williams "metode penelitian kualitatif adalah pengumpulan data dari latar alamiah menggunakan metode ilmiah dan dilakukan oleh orang maupun peneliti yang tertarik secraa alami”.

Penelitian kualitatif ini dilakukan untuk menguraikan permasalahan yang berkaitan dengan penghapusan ujian nasional yang akan diganti dengan sistem asasmen nasional.

Teknik pengambilan dan pengumpulan data dalam penelitian ini dilakukan melalui online dan dokumentasi. Maka dari itu, alasan deigunakannya metode kualitatif dalam penelitian ini, karena penelitian ini berkaitan dengan data-data yang berbentuk deskripsi dan berupa baitbait.

\section{HASIL PENELITIAN DAN \\ PEMBAHASAN}

Pertama kali ujian dikenal di Indonesia yaitu pada zaman Ir. Soekarno di tahun 1950 dengan banyaknya perubahan nama hingga pada tahun 2005 disebut ujian nasional. Ujian nasional merupakan jenis evaluasi akhir pendidikan yang disesuaikan dengan standar pencapaian secara nasional. Evaluasi ujian nasional ini diadakan untuk mencapai beberapa tujuan kegiatan untuk memperoleh, menganalisis, dan menafsirkan data tentang proses dan hasil belajar peserta didik yang dilakukan secara sistematis dan berkesinambungan agar mendapatkan informasi tentang proses belajar mengajar berlangsung. Dari tahun ke tahun ujian nasional mengalami evaluasi mulai dari dampak positif dan negative serta keberlangsungan yang memenuhi tujuan awal diadakan nya ujian nasional. Evaluasi tersebut melahirkan bahwa ujian nasional tidak berjalan secara efektif karena hanya mementingkan satu kemampuan siswanya saja dan tidak melihat kemampuan yang lain bagi siswa nya, itu akan berakibat tidak adil untuk siswa yang kemampuannya bukan di dalam mengerjakan ujian nasional atau kemampuan dalam berfikir. Oleh karena itu di tahun 2021 pemerintah menghapus ujian nasional dan diubah dengan siswam asesmen nasional, penghapusan ini sendiri karena 
ujian nasional tidak berjalan efektif dan tidak berfungsi sebagaimana yang diharapkan untuk kepentingan pembelajaran di sekolah.

Bergantinya ujian nasional dengan cara mendapatkan beberapa informasi tentang pencapaian dan hasil belajar dari peserta didik disekolah atau biasa disebut asasmen yaitu sebuah evaluasi penilaian untuk mendapatkan data pembelajaran selama kelas berlangsung, oleh karena itu kita dapat mengetahui sejauh mana prestasi siswa siswi nya disekolah selama pembelajaran. Jadi system asasment ini sangat berpengaruh dalam bahan evaluasi para pendidik dan siswanya dengan tujuan untuk menjadi lebih baik dari sebelumnya.

System asasment ini berupa kompetensi yang menggantikan ujian nasional di tahun 2021 tentang literasi dan numerasi. Dimana literasi tersebut memuat kemampuan menguasai bahasa dalam teks dengan memahami suatu bacaan sedangkan literasi yaitu memuat tentang kemampuan seseorang dalam menguasai informasi saat melakukan pembelajaran seperti membaca, public speaking, menulis, berhitung, dan memecahkan suatu masalah di kehidupan sehari-harinya serta numerisasi sendiri ini memuat tentang kemampuan berhitung atau dalam pembelajaran matematika untuk memecahkan masalah. Informasi yang didapatkan terdapat dalam bentuk matematis dan kompetensi. Bentuk matematis sendiri berbentuk grafik, table, bagan dan, diagram. Lalu bentuk kompetensi seperti kemampuan wawasan dan pengetahuan. Jadi system baru yang dibuat pemerintah yaitu system asasment ini berkompetensi dalam kemampuan literasi dan numerasi.

Bentuk penilaian dari evaluasi akhir dari system asasment ini sendiri yaitu dalam bentuk survey karakter, diukur secara mendalam dimana asasmen dalam skala besar survey ini, dapat memberikan informasi yang penting tentang sikap, nilai, dan kebiasaan yang mencerminkan profil pelajar Pancasila. Siswa siswinya tersebut akan melakukan evaluasi dengan pertanyaan dari para pendidik tentang Bhineka Tunggal Ika, gotong royong, esensi dari asas Pancasila dan sebagainya. Serta terdapat survey lingkungan belajar dimana mengukur tentang dimana penilaian yang ditunjukan kepada siswa siswinya untuk mengetahui nilai keamanan, kerukunan, kondisi lingkungan rumah, kondisi lingkungan sekolah, dan akhal dari siswa siswinya tersebut. Informasi ini berguna untuk melakukan diagnosis masalah dan perencanaaan perbaikan pembelajaran oleh guru, kepala sekolah, dan dinas pendidikan 
Asasment Nasional diatur dalam UU Sisdiknas Pasal 57 ayat 1 dimana berisi tentang evaluasi dilakukan dalam rangka pengendalian mutu pendidikan secara nasional sebagai bentuk akuntabilitas penyelenggara pendidikan kepada pihakpihak yang berkepentingan serta dalam pasal 59 ayat 1 yaitu tentang pemerintah dan pemerintah daerah melakukan evaluasi terhadap pengelolan, satuan, jalur, jenjang dan jenis pendidikan. Asasment nasional diselenggarakan secara bertahap dimana berjenjang dari SMP/MTS. SMA/SMK/MA, Serta PKBM Paket A, B, dan C pada bulan maret-april 2021 untuk laporan hasil satuan pendidikan untuk SMP/MTS, SMA/SMK/MA dan pendidikan kesetaraan pada bulan juli 2021, untuk pelaksanaan asasmen nasional di SD dan MI pada bulan agustus 2021, dan terakhir untuk laporan hasil rapor satuan untuk SD dan MI pada bulan November 2021.

Perbedaan dari Ujian Nasional dengan Asasment sendiri yaitu ujian nasional dengan format soal PG dan isian singkat dengan komposisi pengetahuan $40 \%$, aplikasi 40\%, penalaran $20 \%$ konteksnya $50 \%$ soal UN tidak menggunakan kontek dengan teks untuk stimulus soal yaitu panjang 2-3 paragraf (100 kata), sedikit ilustrasi. Hanya 1 teks untuk menjawab satu soal dengan format jawaban semua jawaban tunggal. Sedangkan Asasmen Nasioal format soalnya PG, PG kompleks, menjodohkan, isian singkat, dan uraian dengan komposisi pengetahuan $20 \%$, aplikasi $50 \%$, penalaran $30 \%$ konteksnya semua soal diberikan konteks personal, sosial budaya, sains, tek untuk stimulus soalnya panjang bergradasi sesuai kelas di kelas 11 panjang teks 700 kata dengan disertai ilustrasi dan infografis, terdapat soal-soal yang memerlukan pemahaman multiteks dengan format jawaban yang disediakan soal dengan jawaban terbuka.

Dalam pelaksanaan asasmen nasional murid, guru dan sekolah tidak perlu melakukan persiapan yang khusus untuk menghadapi asasment nasional dimana berbeda dengan ujian nasional yang harus disiapkan dari jauh-jauh hari, dalam asasmen hanya perlu dilakukan pengrefleksisan dan memperaiki mutu pembelajaran. Seperti muri tidak perlu menyiapkan diri untuk melaksanakan Asasment nasional. Murid kelas 6, 9, dan 12 cukup menyiapkan diri untuk ujian sekolah dan seleksi masuk jenjang pendidikan selanjutnya. Guru hanya perlu menyiapkan kemampuan untuk melakukan asasment, serta melakukan pembelajaran yang menumbuhkan daya nalar dan karakter secara lebih utuh. Sekolah hanya 
perlu memfasilitasi guru untuk melakukan perbaikan dalan hasil evaluasi tersebut. Orang tua tidak perlu mencari bimbingan belajar untuk anaknya tetapi disarankan untuk membaca lebih luas dan mengembangkan minatnya secara mendalam.

\section{PENUTUP}

Evaluasi menjadi salah satu kunci atau upaya yang akan mengarah dan menjabarkan kepada usulan dan cara agar dapat tercapai satu bentuk akhir yang sesuai dengan kebutuhan, menyamakan dan melinierkan segala bentuk pembahasan hingga akhirnya sesuai dengan kesepemahaman dari pihak yang dimaksudkan. Kebijakan pemerintah yang membuat Ujian Nasioal ini digunakan sebagai sarana untuk meningkatkan kualitas bangsa, denga Ujian Nasional sebagai patokan evaluasi akhir pendidikan ini dapat membantu membandingkan tingkat kualitas pendidikan bangsa saat ini dengan tahun sebelumnya. Mengapa akhirnya harus untuk dihapuskan karena sejatinya Kurang efektifnya penyelenggara ujian untuk evaluasi pendidikan akhir antara lain karena lemahnya koordinasi antara pemerintah daerah untuk mengoptimalkan pengawasan distribusi soal dari pusat sehingga sampai ketingkat daerah. Di infokan bahwa pada tahun ini (2021) akan dihapuskan ujian nasional dan diganti dengan system assessment nasional oleh menteri pendidikan Indonedia Nadiem Makarim. Oleh karena itu adanya banyak pro dan kontra terhadap pelaksanaan kebijakan ini membuat pihak pihak yang terlibat dalam merancang dan melaksanakan kebijakan menjadi harus mencocokan cara atau gaya agar sesuai dengan harapan dalam kebijakan yang baru, upaya untuk saling mendukung dari berbagai pihak tentunya akan terus bersinergi terhadap kesuksesan pelaksanaan kebijakan baru ini dan semoga apa yang diharapkan dapat terwujud dan sesuai dengan kenyataan yang ada.

\section{DAFTAR PUSTAKA}

Kementrian Pendidikan dan Kebudayaan. Penyelenggaraan Asasmen Nasional Tahun 2021. Balitbang dan Perbukuan. 7

Desember 2020.

Nursyam. 2017. Efektivitas Pelaksanaan Ujian Nasional Tingkat Sekolah Menengah Atas Negeri Oleh Dinas Pendidikan dan Pengajaran Kota Palu Provinsi Sulawesi Tengah. Vol 2 No 9. Hlm 11-21.

Simbolon K. Ujian Nasional Sebagai Penentu Kelulusan Merugikan Peserta Didik. Universitas Kristen Indonesia. 
Kementrian Pendidikan dan Kebudayaan Republik Indonesia. Kebijakan Perubahan Ujian Nasional. 23 Januari 2015.

Safitri. 2019. Dampak Penghapusan Ujian Nasional Yang Akan Diganti Dengan Sistem Asasmen Kompetensi dan Survey Karakter. Vol 3 No 2.

Sartina, Nursiang, Faisal. Analisis

Kebijakan Ujian Nasional Terhadap

Evaluasi Akhir Pendidikan. IAIN Bone 